\title{
A NEW SPECIES OF PLEUROTHALLIS (ORCHIDACEAE: PLEUROTHALLIDINAE) FROM VALLE DEL CAUCA, COLOMBIA AND A NOTE ON THE RELATIONSHIP BETWEEN SUBSECTIONS MACROPHYLLAE-RACEMOSAE AND ANTENNIFERAE
}

\author{
Mark Wilson ${ }^{1,10}$, Katharine Dupree $^{1}$, Diana Garcia Lopera ${ }^{2}$, David Haelterman ${ }^{3}$, \\ Andreas Kay ${ }^{4}$, Carlos Mesa Londoño ${ }^{5}$, Andrea Niessen ${ }^{6}$, William Pinnix 7 , \\ José Portilla ${ }^{8} \&$ Jon D. Werner ${ }^{9}$
}
${ }^{1}$ Department of Organismal Biology and Ecology, Colorado College, Colorado Springs, CO 80903, U.S.A.
${ }^{2}$ Vereda Montañita, San Antonio de Prado, Medellín, Antioquia, Colombia
${ }^{3}$ Calle 56, 4b-145 casa 4a condominio San Francisco, Cali, Colombia
${ }^{4}$ Fundación EcoMinga, Baños, Tungurahua, Ecuador
${ }^{5}$ Calle 33 sur No. 4518 Envigado, Antioquia, Colombia
${ }^{6}$ Orquideas del Valle, Calle 10N \#9-31, Cali, Colombia
${ }^{7} 1825$ Brindle Lane, Eureka, CA 95501, U.S.A.
${ }^{8}$ Ecuagenera, Km. 2 1/1 Vía a Cuenca Sector Llampasay, Gualaceo, Ecuador
${ }^{9} 8117$ Northway SW, Lakewood, WA 98498, U.S.A.
${ }^{10}$ Author for correspondence: email: mwilson@coloradocollege.edu

\begin{abstract}
A new species of Pleurothallis from subsection Macrophyllae-Racemosae is described from Valle del Cauca, Colombia. Morphological characteristics to distinguish this species from Pleurothallis bicornis, $P$. subreniformis and P. torrana are presented. The micromorphology of the lip of the new species was studied utilizing scanning electron microscopy. Labellar micromorphology is discussed in relation to putative pollination mechanisms.
\end{abstract}

Key words: Antenniferae, glenion, labellum, Macrophyllae-Racemosae, Pleurothallis, pollination

Introduction. Pleurothallis section MacrophyllaeRacemosae was created by Lindley (1859). Luer (1988) demoted the section to subsection MacrophyllaeRacemosae, joining Pleurothallis subsections Acroniae, Antenniferae, Longiracemosae and MacrophyllaeFasciculatae. Luer (1999) in Icones Pleurothallidinarum XVIII recognized 37 species in the subsection with the type being Pleurothallis lindenii Lindl. Since that monograph on the subsection only Pleurothallis papillingua A.Doucette \& J.Portilla has been described. At this time, the group can be considered to contain between 38 and 50 species, depending on synonymy. However, Luer (1999) acknowledged that "All the subsections are interrelated, sometimes with overlapping boundaries and intermediate species". In particular, there seems to be a high degree of morphological overlap between subsections Macrophyllae-Racemosae and Antenniferae. Indeed, there is no single morphological character or group of characters that can reliably place a species in subsection Macrophyllae-Racemosae versus Antenniferae.

Unfortunately, the molecular phylogenetic study of the Pleurothallidinae by Pridgeon, Solano and Chase (2001) did not include representatives of either subsection and, therefore, provided no information on whether the two groups should be merged into a single taxonomic unit. The ongoing phylogenetic studies of Pleurothallis by Wilson et al. $(2011,2013)$ and Wilson (unpubl. data) utilizing nuclear internal transcribed spacer (nrITS) and plastid matK sequences, incorporating representatives of both subsections, indicate that while there is a strongly-supported clade for subgenus Pleurothallis (at least if subsection Macrophyllae-Fasciculatae is excluded), there is only weak support for groupings below the level of subgenus. In other words, preliminary phylogenetic data do not support a distinction between subsections Macrophyllae-Racemosae and Antenniferae. 
Considering this and the lack of a discriminatory morphological character, the two subsections might be considered a single group. Since subsection Antenniferae contains 38 to 49 species, depending on synonymy (Luer 1999), the two subsections together would include somewhere between 76 and 99 species.

If we consider the two subsections as a single group, the species are distributed from Central America (Pleurothallis colossus Kraenzl. ex Kerch. and Pleurothallis crescentilabia Ames) through the Andean countries of Venezuela, Colombia, Ecuador and Peru, as far south as Bolivia (Pleurothallis antennifera Lindl., Pleurothallis demissa Luer \& R.Vásquez, Pleurothallis lamellaris Lindl. and Pleurothallis saltatoria Lindl.); one species occurs in Guyana and Suriname (Pleurothallis suspensa Luer); and one species occurs in the Caribbean (Pleurothallis revoluta (Ruiz \& Pav.) Garay) (Luer 1999). Based on the number of collected species, Ecuador would appear to be the center of diversity for this group, however, there is probably a collection bias, since, until recently, Colombia was less accessible than Ecuador.

The species of Pleurothallis in the MacrophyllaeRacemosae/Antenniferae group are frequently misidentified. For example, P. lindenii and Pleurothallis secunda Poepp. \& Endl. have been repeatedly confused (Luer 1999). In part this is because, aside from a few very easily identifiable species such as P. colossus and P. hemisphaerica Luer \& R.Escobar, identification relies heavily upon the morphology of the labellum or "lip" and in particular the presence or absence of calli, which usually requires dissection of the flower. Such is the case in distinguishing the almost identical Pleurothallis magnifica Luer \& R.Escobar and Pleurothallis orthostachys Luer \& R.Escobar. Indeed, because of the morphological similarity of the species in the Macrophyllae-Racemosae/Antenniferae group, confusion among the described species and scant attention paid to the group, there may well be many more than the estimated 76-99 species for the two combined subsections. In this paper we describe the first of a series of new species in the MacrophyllaeRacemosae/Antenniferae group.

Relatively little is known about pollination of species of Pleurothallis sensu Pridgeon, Cribb, Chase \& Rasmussen (2005), but the genus is presumed to be pollinated predominantly by Diptera. Pollination in the Macrophyllae-Racemosae/Antenniferae group has been studied more than any other group within the genus. Duque (1993) reported Pleurothallis lindenii (as Pleurothallis secunda) was pollinated primarily by Diptera while Pleurothallis aves-seriales Luer \& R.Escobar (possibly Pleurothallis antennifera) was pollinated by Diptera and Hymenoptera. CalderónSáenz (2011) observed pollination of Pleurothallis colossus by Anthomyiid flies. Although unable to perform in situ pollination studies on the new species, in this paper we present data on lip morphology from macro-photography and scanning electron microscopy (SEM) and discuss labellar morphology in relation to putative pollination mechanisms.

\section{Materials and Methods}

Plant material - . Plant material of the new species described in this article was examined in situ in Valle del Cauca, Colombia. Plant material was also examined in the collections of: Orquídeas del Valle, Cali, Colombia, where the plant was grown as P. bicornis; Carlos Mesa Londoño, Medellín, Colombia; Libia Orquídeas, Medellín, Colombia; and Ecuagenera, Gualaceo, Ecuador, where the plant was grown as P. torrana. Plants were imported into U.S.A from Ecuagenera as P. torrana, without collection data, and grown in cultivation by Wilson in Colorado and Pinnix in California. Material from these latter plants was used for the creation of the Lankester composite digital plate (LCDP) of the new species and for creation of herbarium specimens accessioned into the herbarium at Colorado College (COCO). Flowers of the studied species were preserved in Kew Mix (5\% formalin [37.6\% formaldehyde], 53\% methanol, $5 \%$ glycerol, $37 \%$ deionized water).

Taxonomic comparisons-. In order to determine novelty of the species described herein, plant material was first compared to species with which this plant had previously been confused, including $P$. bicornis and $P$. torrana, as well as with the similar species, Pleurothallis subreniformis Schltr. (Luer 1999). The putative new species was compared to descriptions of Colombian and Ecuadorian species from all pertinent literature: Dodson (2003), Dodson and Dodson (1980, 1982), Escobar (1994, 2006), Luer (1974, 1975a, 1975b, 1976, 1977, 1986, 1988, 2005, 2009, 2011) and Luer and Thoerle (2013). 
Labellar micro-morphology-. Flowers were prepared for and examined by SEM using methods described previously (Wilson et al. 2016).

\section{Results}

Initial observations- The new species was initially noticed by the first author in October 2009 among photos from the collection of Lynn O'Shaughnessy on the website of the Pleurothallid Alliance, listed as Pleurothallis sp. (O'Shaughnessy 04008) from Colombia. The species (Fig. 1) was subsequently observed by the first author in the collections of Ecuagenera, as P. torrana, and Orquídeas del Valle, as P. bicornis. Preliminary comparison of the species to the drawings and descriptions of similar species (Fig. 2, Luer 1999) suggested that this plant was not $P$. bicornis, P. torrana, or the somewhat similar P. subreniformis.

Taxonomic comparisons - Dimensions of the plant and flowers of the new species were compared to those of P. bicornis (Figs. 2A, 3), P. subreniformis (Figs. 2B, 4) and P. torrana (Fig. 2C) (Table 1). Particular emphasis was applied to a comparison of the lip of the putative new species with those of the described species (Fig. 5). Morphological comparisons of Pleurothallis caucensis sp. nov. to the three aforementioned species, and to the other species in Pleurothallis subsections Macrophyllae-Racemosae and Antenniferae, indicated that this was indeed a previously undescribed species.

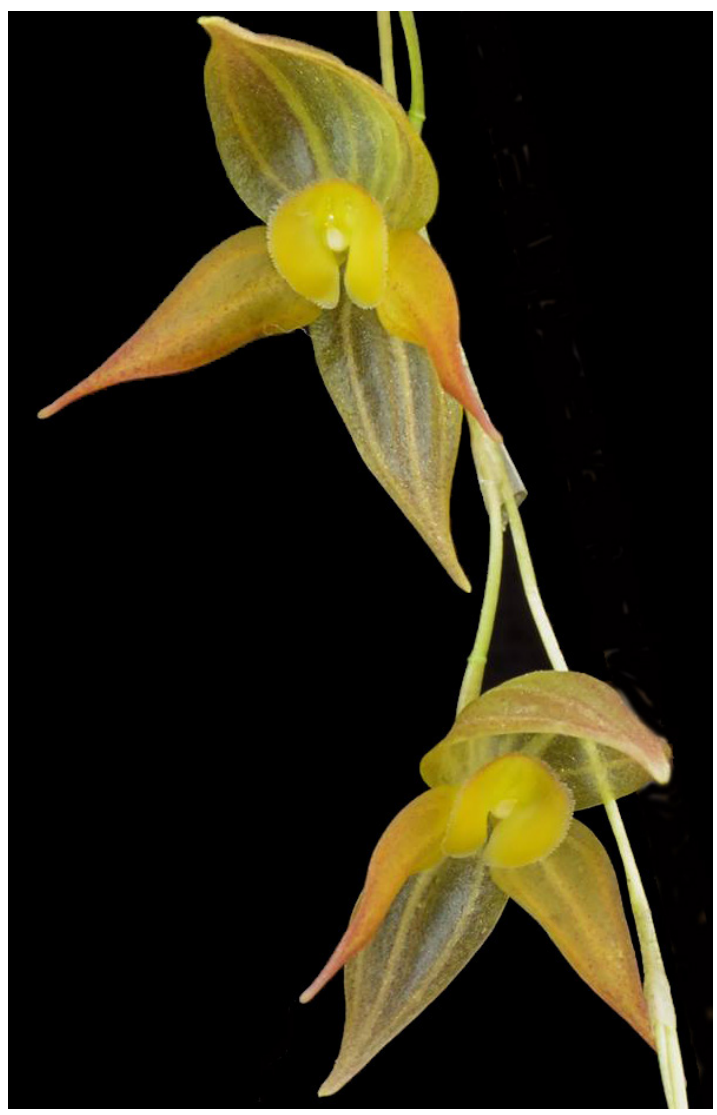

Figure 1. Pleurothallis caucensis (yellow form). Photograph by William Pinnix from paratype M. Wilson, W. Pinnix \& J. Portilla PL0976.

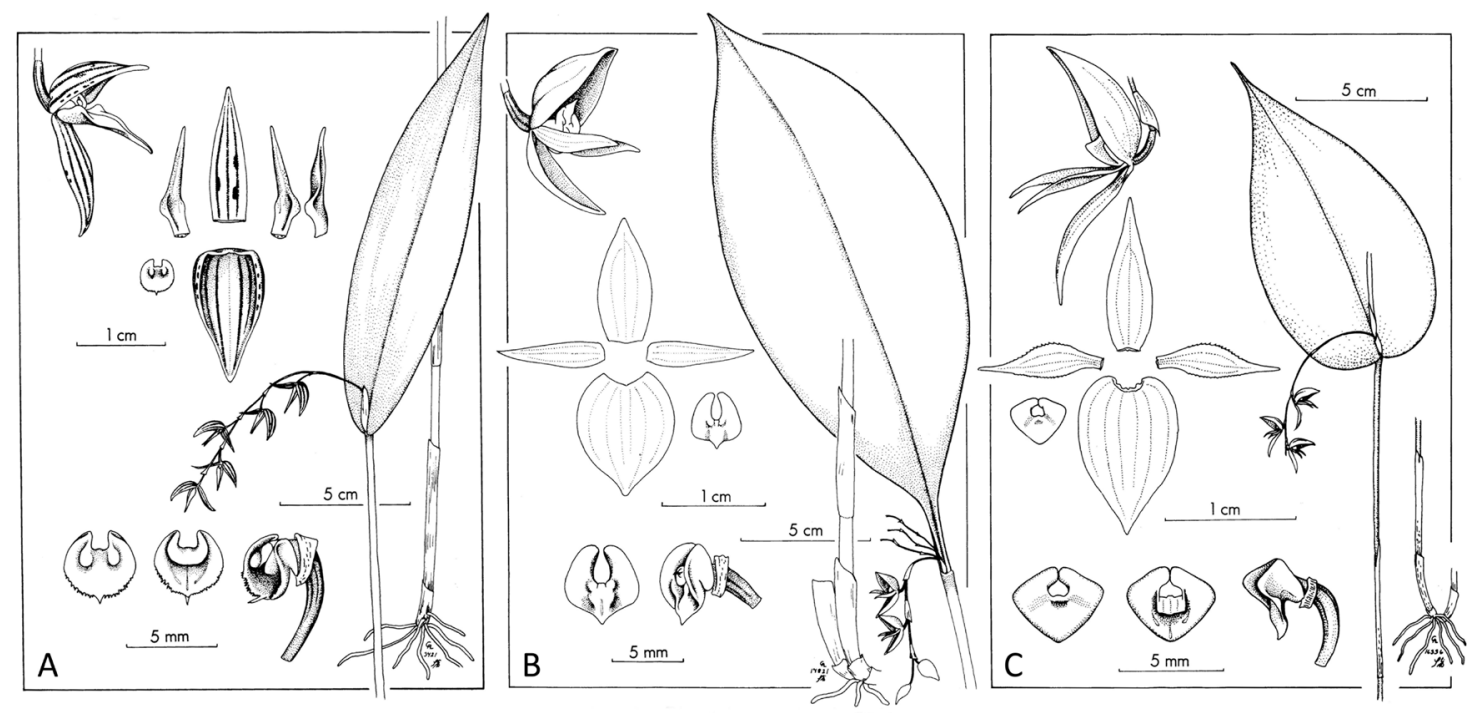

FIGURE 2. Drawings of A - Pleurothallis bicornis; B - Pleurothallis subreniformis; and C - Pleurothallis torrana (from Luer 1999, courtesy of Missouri Botanical Garden Press). 


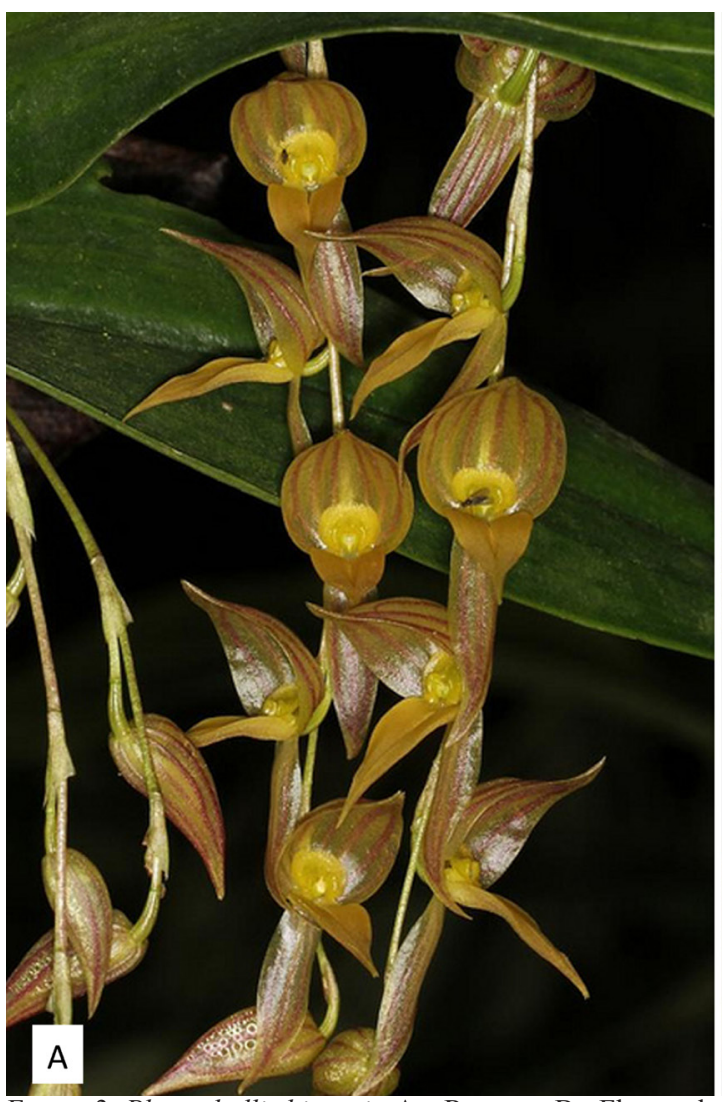

FIgURE 3. Pleurothallis bicornis. A - Raceme; B - Flower detail. Photographs by Lourens Grobler.

Geographic distribution of morphologically similar Macrophyllae-Racemosae/Antenniferae-. The new species was photographed in situ (Fig. 6) on the eastern side of the Cordillera Occidental, near Calima Lake, in the Department of Valle del Cauca, Colombia (Fig. 7) in December 2015 by Haelterman. To our knowledge it has not been photographed in situ or collected from the wild in Ecuador where it appears to only occur in a commercial collection. Pleurothallis torrana is believed to be endemic to Cerro Torrá, on the western or Pacific side of the Cordillera Occidental, near Sipí, in the Department of Chocó, Colombia (Fig. 7) (Luer 1999). The similar species P. bicornis (Fig. 8) and $P$. subreniformis (Fig. 9) have both been photographed by Kay in the forests of NW Ecuador, but their occurrence in adjacent areas of Colombia has not been confirmed.

Labellar micromorphology-. The lips of $P$. caucensis, $P$. bicornis and $P$. subreniformis each exhibit longitudinally-oriented calli on the central lobe of the lip. In P. caucensis the calli are poorly-

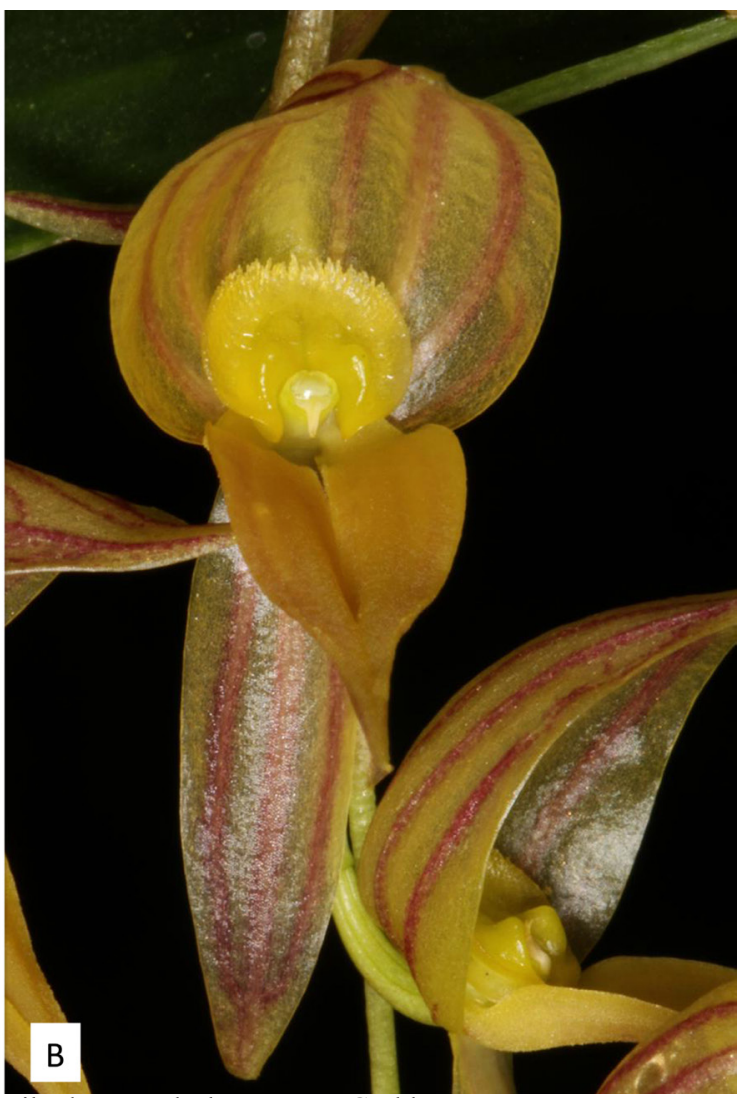

developed and lunate in top-view (Figs. 10-11). They flank a channel in front of the anther and an indistinct, small glenion immediately below the viscidium. In $P$. bicornis the calli are large and triangular in side-view, short and partially lunate in top view (Figs. 3B, 5A). In $P$. subreniformis the calli are low and rounded in side-view and long, lunate in top-view (Figs. 4B, 5B). Interestingly, the lip of $P$. caucensis exhibited liquid droplets, possibly nectar, on the anterior margin of the central lobe (Fig. 10). When examined by SEM from the anterior edge of the central lobe of the lip towards the anther, the relief of the lunate calli and the channel created between them was more apparent (Fig. 11). This channel bore the dehydrated remains of liquid, represented only by a thin, desiccated film.

\section{Taxonomy}

Pleurothallis caucensis Mark Wilson, sp. nov. (Figs. $1,6,10,11,12,13)$

TYPE: Colombia. Flowered in cultivation as $P$. 

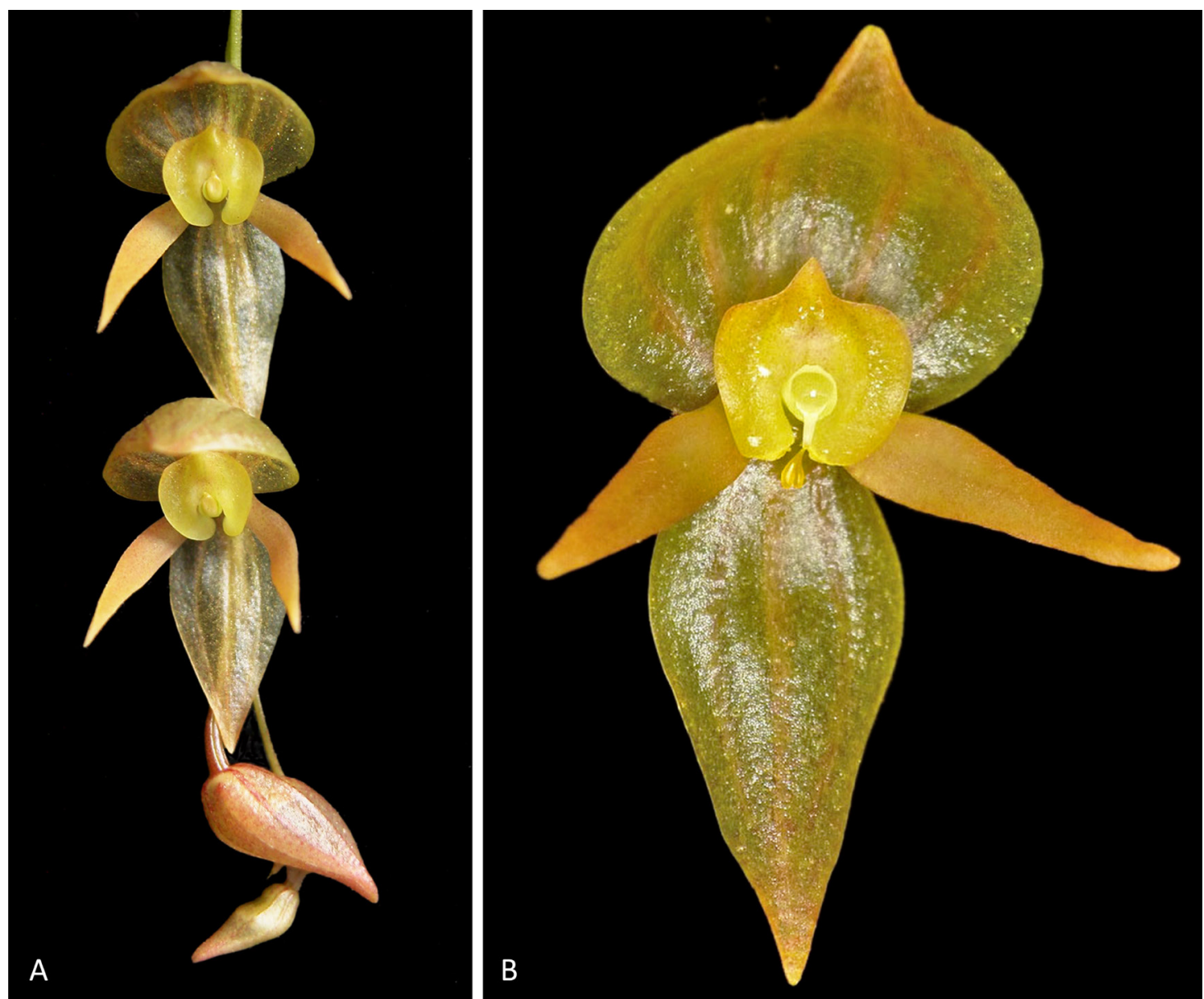

Figure 4. Pleurothallis subreniformis. A - Raceme; B - Flower detail. Photographs by Wilson (A) and Andreas Kay (B).

TABle 1. Comparison of morphology and dimensions of Pleurothallis caucensis (this study, derived from all available material) with Pleurothallis bicornis, Pleurothallis subreniformis and Pleurothallis torrana (data from Luer 1999).

\begin{tabular}{|c|c|c|c|c|}
\hline Plant part & P. caucensis & P. bicornis & P. subreniformis & P. torrana \\
\hline Ramicaul length $(\mathrm{cm})$ & $45-75$ & $35-75$ & $40-92$ & $17-35$ \\
\hline Leaf size $(\mathrm{cm})$ & $11-28 \times 4.5-11.2$ & $15-22 \times 4-9.5$ & $25-31 \times 8-14$ & $13-14 \times 6.5-7$ \\
\hline Raceme length (cm) & $11.5-16.3$ & $10-18$ & $5-8$ & $\sim 8$ \\
\hline Dorsal sepal (mm) & $14-15 \times 12-13$ & $13-17 \times 3.5-6$ & $12 \times 4.5-5.5$ & $12 \times 3.75$ \\
\hline Synsepal (mm) & $16-18 \times 8-10$ & $13-17 \times 14-16$ & $11-12 \times 8-9$ & $12 \times 8$ \\
\hline Petals (mm) & $15-19 \times 5-6$ & $12-16 \times 2.75-3.5$ & $10 \times 2$ & $9.5 \times 2.5$ \\
\hline Lip (mm) & $5-6 \times 5-6$ & $3.5-4 \times 4-5$ & $3 \times 4.5-5$ & $2.25-4.25$ \\
\hline Lip shape & suborbicular & suborbicular & hippocrepiform & subrhombic \\
\hline Lip callus/calli & $\begin{array}{l}\text { low calli in front of } \\
\text { anther }\end{array}$ & $\begin{array}{l}\text { large calli in front of } \\
\text { anther }\end{array}$ & low rounded calli & small transverse callus \\
\hline Fimbriae & $\begin{array}{l}\text { short fimbriae all } \\
\text { around lip }\end{array}$ & $\begin{array}{l}\text { long fimbriae at apex } \\
\text { only }\end{array}$ & no fimbriae & no fimbriae \\
\hline
\end{tabular}


bicornis by Carlos Augusto Mesa Londoño in Envigado, Colombia, Jan 27, 2017, M. Wilson \& C. A. Mesa Londoño PL0993 (holotype: JAUM!).

Diagnosis. Pleurothallis caucensis can be distinguished from $P$. bicornis by the petals, which in P. caucensis are free, projected laterally and downward and in $P$. bicornis are adpressed and project forwards; by the lip which is completely fimbriated in P. caucensis and only fimbriated on the margin of the central lobe in P. bicornis; and by the lateral lobes of the lip which are flattened and surpass the column in $P$. caucensis and which are auriculate, not surpassing the column in P. bicornis. Pleurothallis caucensis differs from $P$. subreniformis in the length of the raceme, sepals and petals, which are longer in $P$. caucensis than in $P$. subreniformis (Table 1); and in the lip shape, which is suborbicular in P. caucensis and hippocrepiform with an acute apex on the midlobe in P. subreniformis. Pleurothallis caucensis differs from $P$. torrana in the length of the ramicauls, raceme, sepals and petals, all of which are longer in P. caucensis than in P. torrana (Table 1); in the lip shape which is suborbicular in $P$. caucensis and rhombiform in P. torrana; and in the
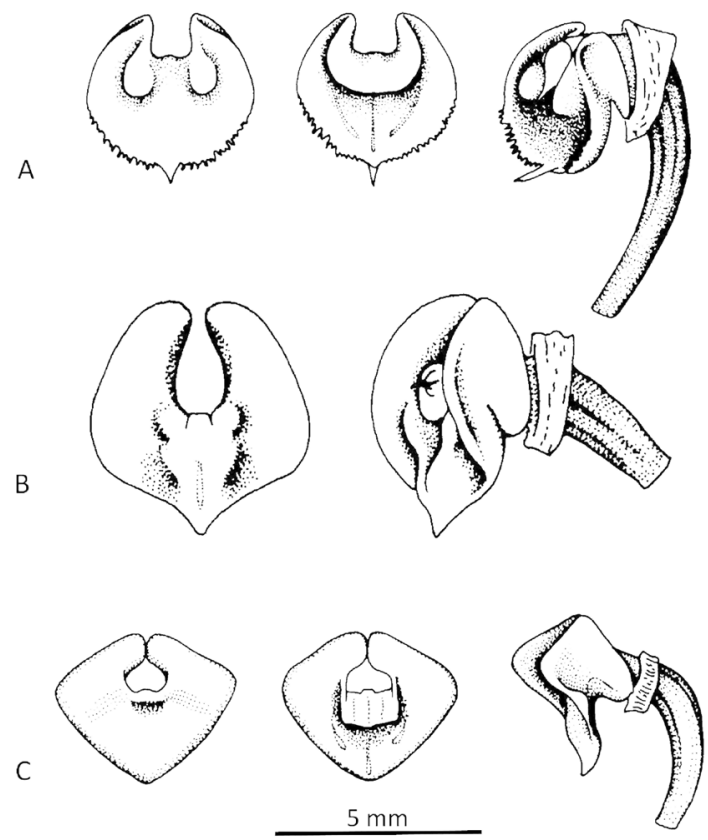

FigURE 5. Drawings of lips of A - Pleurothallis bicornis; B - Pleurothallis subreniformis; and C - Pleurothallis torrana. Drawings from Luer 1999, courtesy of Missouri Botanical Garden Press..
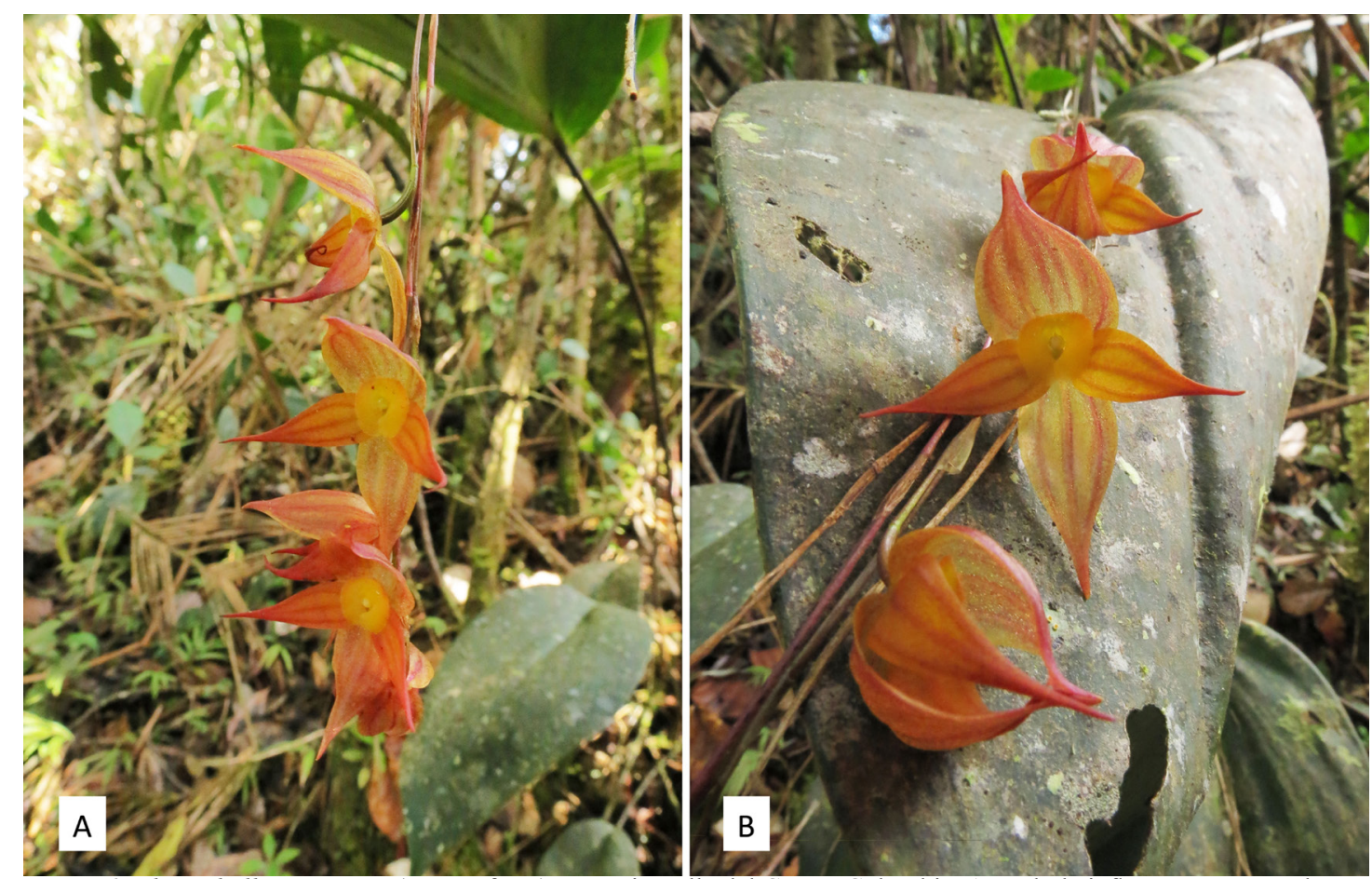

FiguRE 6. Pleurothallis caucensis (orange form) in situ in Valle del Cauca, Colombia: A - Whole inflorescence; B - Flower front view. Photographs by David Haelterman. 


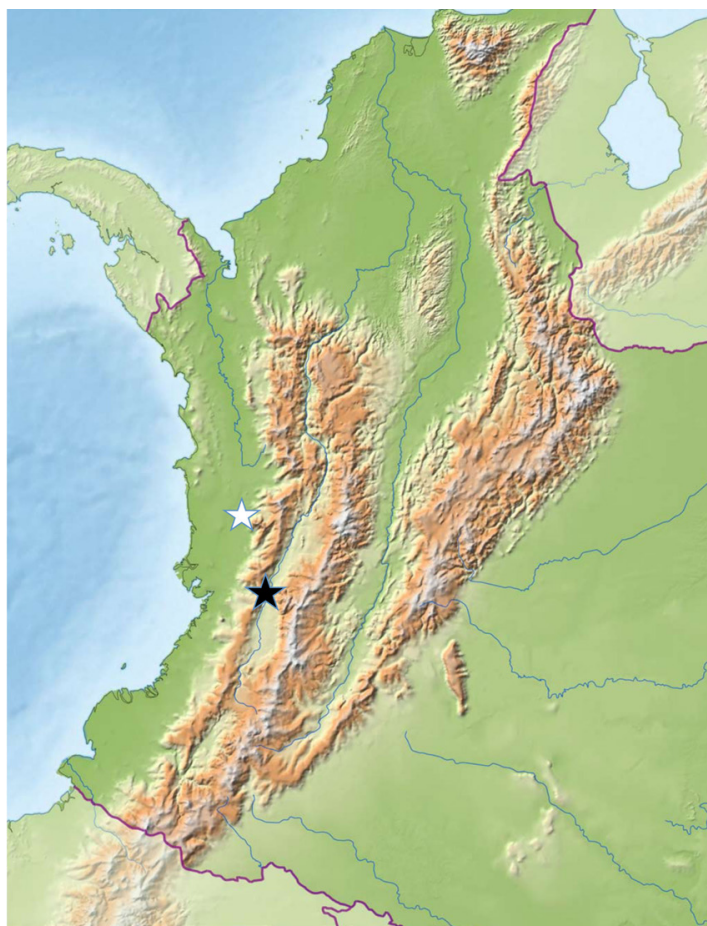

FIGURE 7. Topographical map of Colombia indicating only known locality of Pleurothallis caucensis (black) and type locality of Pleurothallis torrana (white). Map courtesy of Freeworldmaps.net.

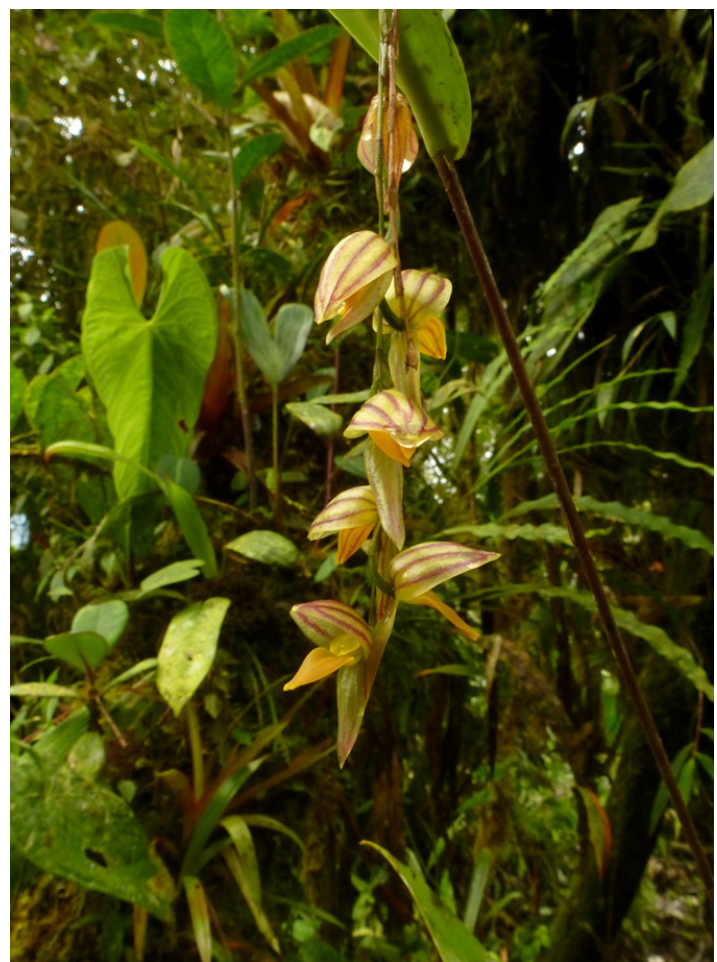

FIGURE 8. Pleurothallis bicornis in situ in NW Ecuador. A Plant with inflorescences; B - Detail of inflorescences. Photographs by Andreas Kay.

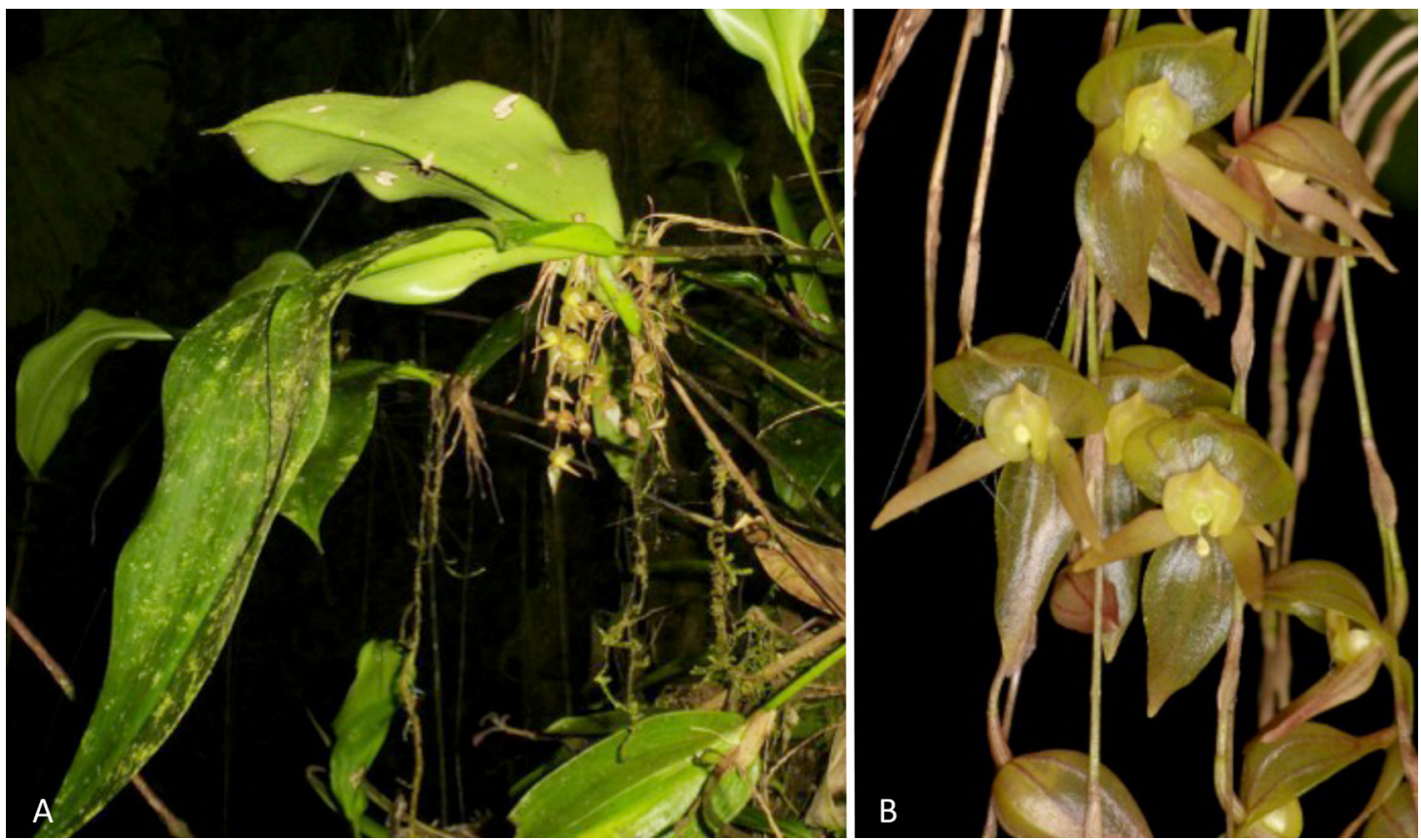

FIGURE 9. Pleurothallis subreniformis in situ in NW Ecuador. A - Plant with inflorescences; B -Detail of inflorescences. Photographs by Andreas Kay. 


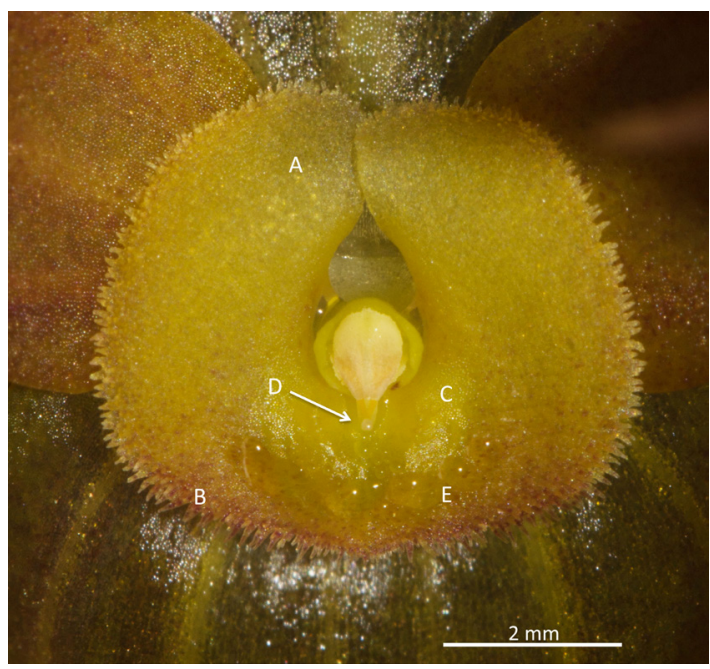

FIgURE 10. Lip and column of Pleurothallis caucensis. A Basal lobes of lip; B - Fimbriate margin of central lobe of lip; C - Lunate calli; D - Glenion below viscidium; E - Nectar-like liquid on central lobe of lip. Photograph by Carlos Mesa from M. Wilson \& C. A. Mesa Londoño PL0993

lip callus, which consists of a pair of lunate calli in $P$. caucensis and a single transverse callus in $P$. torrana.

Plant large, terrestrial, caespitose, $\sim 79-94 \mathrm{~cm}$ tall. Roots fibrous, coarse. Ramicaul spreading, terete, 45-75 $\mathrm{cm}$, with basal sheath $4.55-7.20 \mathrm{~cm}$ long and mid-sheath, 7.3-9.2 cm long. Leaves sub-erect, becoming pendent, ovate, acuminate, cuneate, $11-28 \times 4.5-11.2 \mathrm{~cm}$, entire. Inflorescence 1 pendent raceme per leaf, 3-8 flowers per raceme, $11.5-16.3 \mathrm{~cm}$ long, from reclining spathaceous bract $1.8-2.6 \mathrm{~cm}$ long, floral bract infundibular, 6-8 $\mathrm{mm}$ long. Pedicel 4.0-5.6 mm long. Ovary 7.0-10 $\mathrm{mm}$ long. Flowers non-resupinate in presentation, 2-3 $\times 1.6-1.8 \mathrm{~cm}$. Dorsal sepal yellow lightly suffused with red-brown to darker orange-brown increasing in density toward apex, ovate, acute-acuminate, 14-15 $\times$ 12-13 mm, entire, glabrous, 3-veined. Synsepal yellow lightly suffused with red-brown to darker orange-brown increasing in density toward apex, ovate, concave, acute-acuminate, 16-18 × 8-10 mm, entire, glabrous, 6-veined. Petals yellow lightly suffused with redbrown increasing in density toward apex, lanceolate, acuminate, cuneate-humerate at base, 15-19 × 5-6 $\mathrm{mm}$, entire, glabrous, 3-veined. Lip yellow, tri-lobed, infused with red-brown along margin of central lobe, suborbicular, 5-6 mm diameter, fimbriate, lateral lobes rounded, flanking the column, central lobe with two poorly-developed rounded lunate calli on central lobe in front of anther, small glenion below anther. Column yellow, stout, short, $2.8-3.1 \times 0.8-1.0 \mathrm{~mm}$, tightly fused to lip, anther apical, anther cap yellow.

Additional material studied: Colombia. Flowered in cultivation as $P$. bicornis by Diana Garcia Lopera in Medellín, Colombia, Jan 27, 2017, M. Wilson \& D.

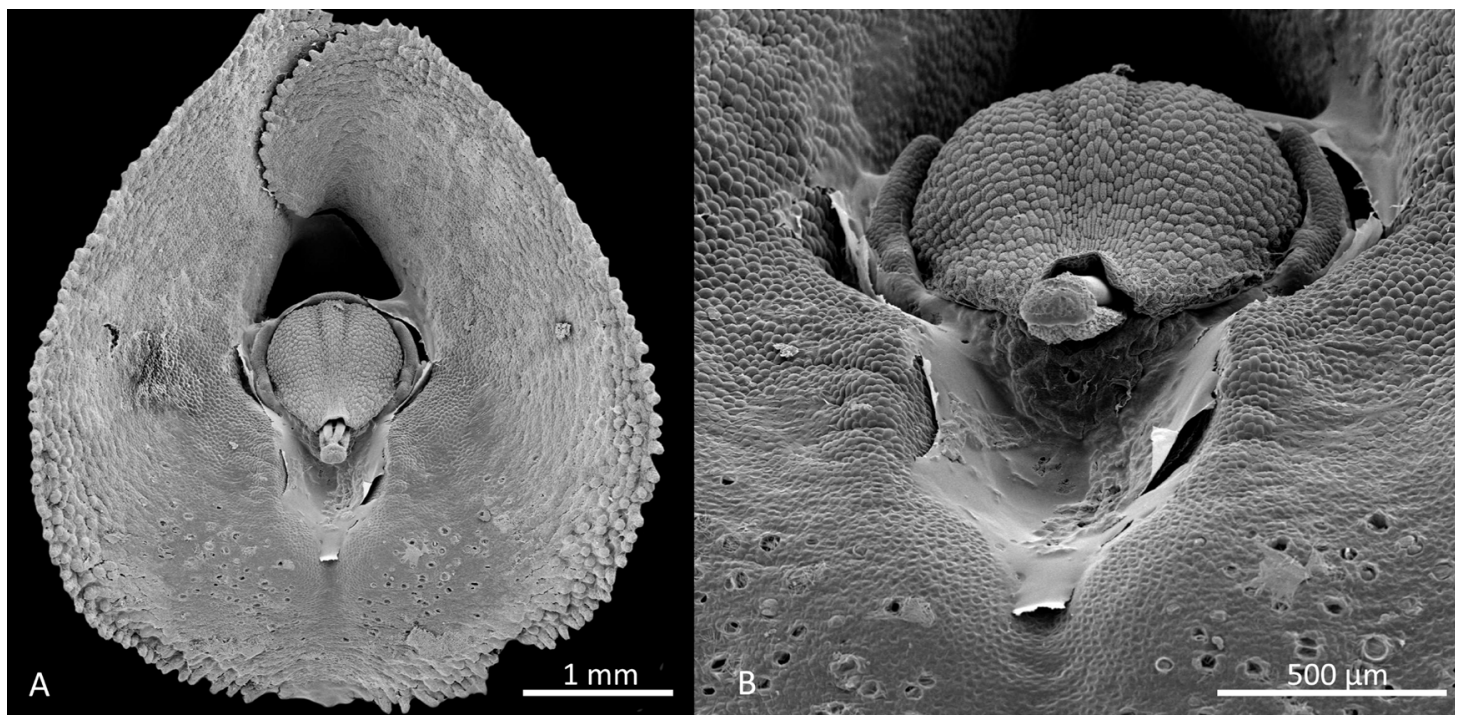

FIGURE 11. Scanning electron micrographs of Pleurothallis caucensis: A - Lip and anther; B - Detail of anther, viscidium and lip with calli. Micrographs by Katharine Dupree prepared from the paratype M. Wilson \& J. Portilla PL0756. 


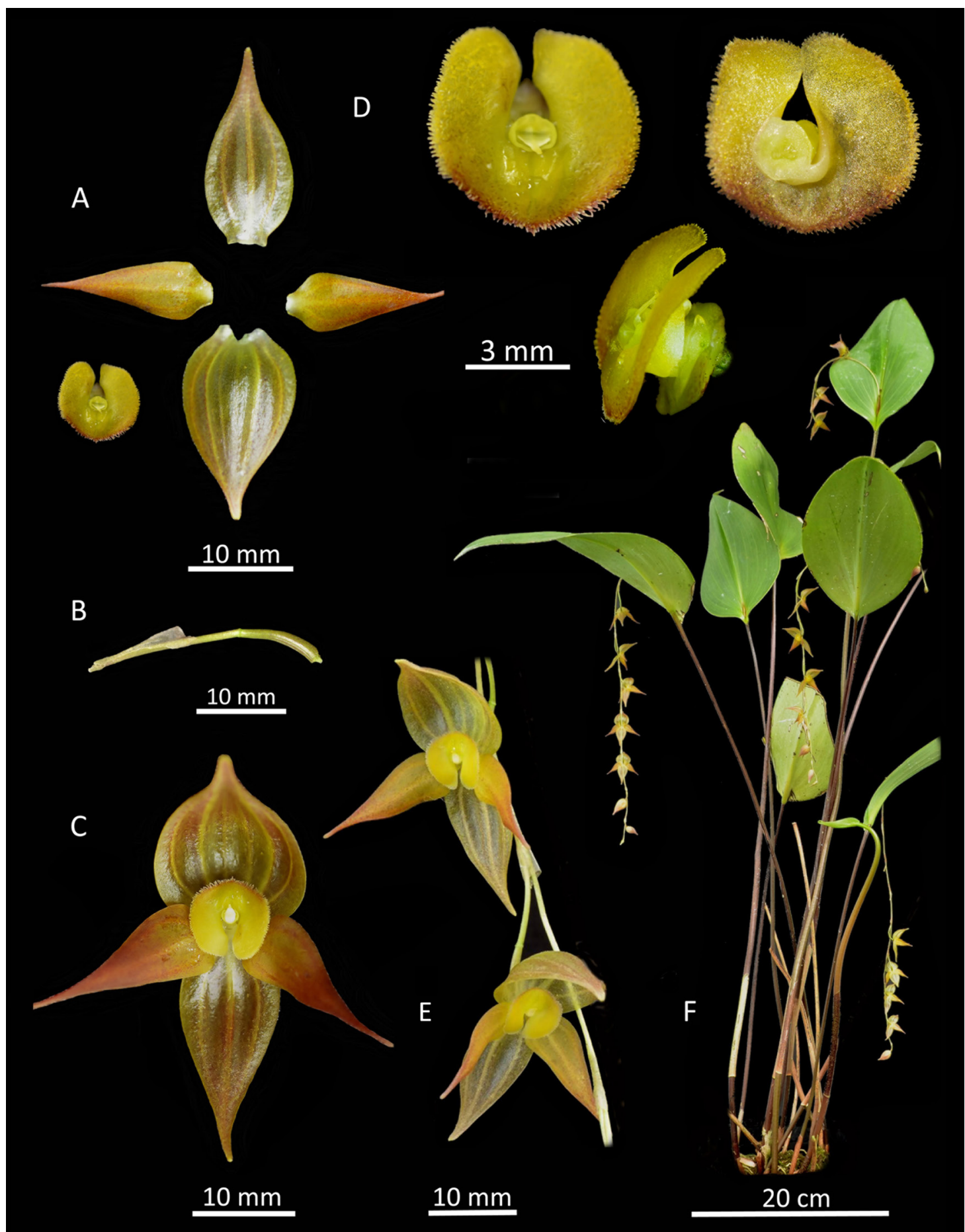

FIGURE 12. Lankester composite digital plate of Pleurothallis caucensis: A - Floral dissection; B - Pedicel, floral bract and ovary; C - Whole flower; D - Lip (front, rear and side); E - Partial raceme with flowers in non-resupinate orientation; F - Whole plant with inflorescences. LCDP prepared by Mark Wilson from the paratype M. Wilson,W. Pinnix \& J. Portilla PL0976 


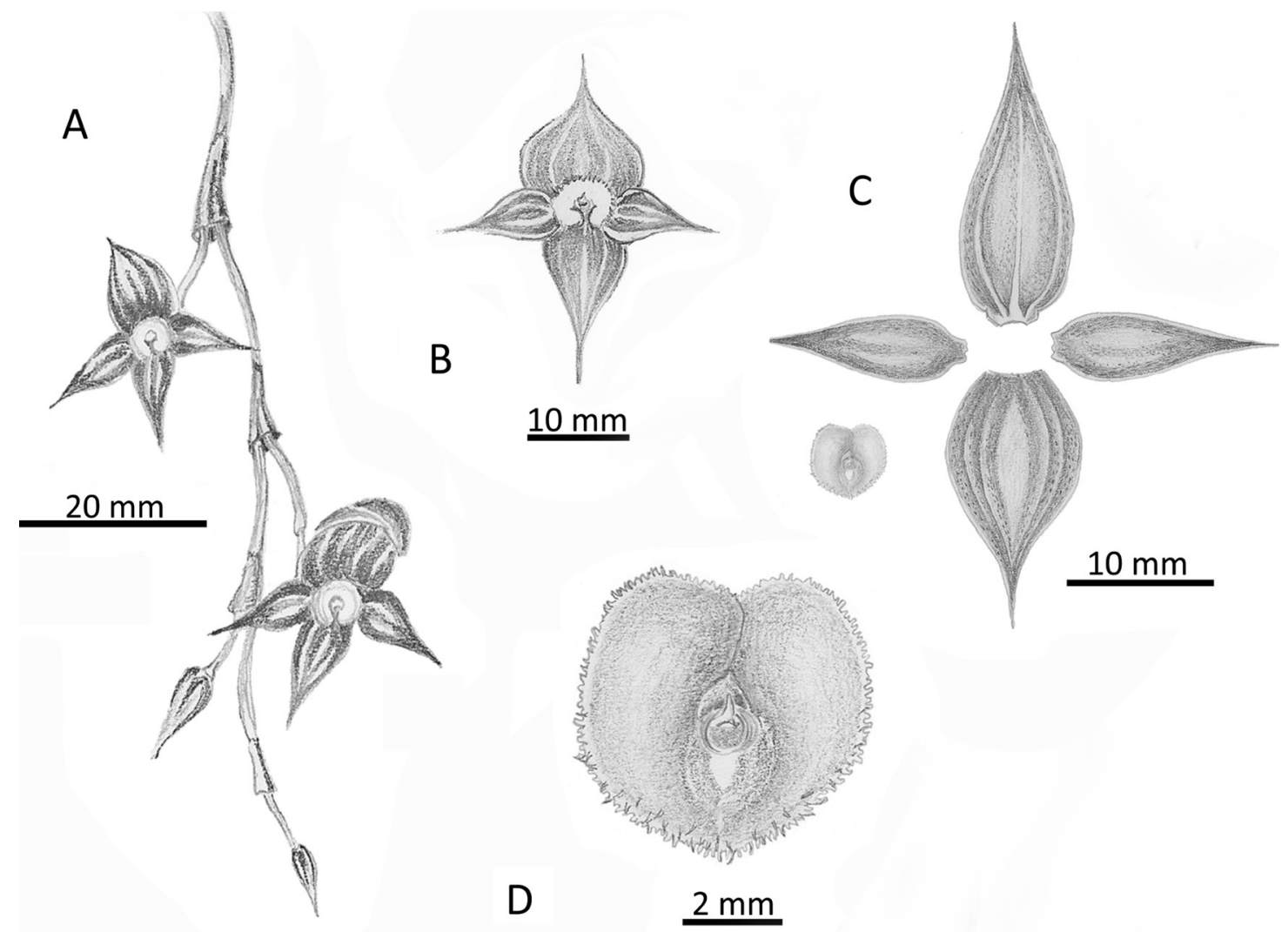

FIGURE 13. Drawing of Pleurothallis caucensis: A - Inflorescence; B - Whole flower; C - Floral dissection; D - Lip. Drawn by Jon Werner from the paratype M. Wilson, W. Pinnix \& J. Portilla PL0976.

García Lopera PL0994 (paratype: JAUM!). Flowered in cultivation as P. bicornis by Andrea Niessen in Cali, Colombia, M. Wilson \& A. Niessen PL0995 (paratype: CUVC!). Ecuador. Purchased from Ecuagenera as $P$. torrana, without collection data, and flowered in cultivation in Colorado M. Wilson \& J. Portilla PL0756 (paratype: COCO!). Purchased from Ecuagenera as P. torrana, without collection data, and flowered in cultivation in California M. Wilson, W. Pinnix \& $J$. Portilla PL0976 (paratype: COCO!).

Eтymology: Named in reference to the only known locality of the species in Valle del Cauca, Colombia.

Distribution AND habitat: Pleurothallis caucensis was observed growing terrestrially among dead leaves at an altitude of $\sim 1800 \mathrm{~m}$ in the vicinity of montane forest near Calima Lake, Department of Valle del Cauca, Colombia. Other orchids in the vicinity included Masdevallia caesia and Houlletia odoratissima. To date, P. caucensis has not been observed in neighboring Ecuador, despite occurring in collections in that country. It is possible, however, that it occurs in forests of northern Ecuador, in which case, collections from that region may exist in herbaria misidentified as P. bicornis, $P$. subreniformis or P. torrana. Until the presence of $P$. caucensis in Ecuador can be verified, it should not be added to the flora of that country.

Conservation status: The location in which $P$. caucensis was observed growing naturally is not in a protected area and cannot be considered secure. Although $P$. caucensis occurs in collections in Colombia, Ecuador, U.S.A and England, the level of genetic variation among these plants is unknown, so the value of these collections for ex situ conservation cannot be assessed.

\section{Pleurothallis subsection Macrophyllae-} Racemosae is the third most species-rich group in subgenus Pleurothallis after subsections Macrophyllae-Fasciculatae and Acroniae; or if we 
consider subsections Macrophyllae-Racemosae and Antenniferae to represent a single taxonomic group, then the combined subsection rises to second most species-rich. The description of $P$. caucensis brings the total in the combined group to 77-100 species, depending on synonymy. However, there are probably many more species in the group to be described, since the group has received less attention than others within Pleurothallis sensu Pridgeon et al. (2005), this being only the second new species since the monograph by Luer (1999).

While $P$. caucensis is superficially similar to $P$. bicornis, $P$. subreniformis and $P$. torrana, there is no question that it is a distinct species and the information provided in this study should allow easy discrimination of the four species in future. It is still unknown whether any of these four occur sympatrically. Although $P$. caucensis and $P$. torrana occur relatively close together in SW Colombia, P. caucensis occurs on the eastern slope of the Cordillera Occidental of the Andes in the Department of Valle del Cauca and P. torrana occurs on the western or Pacific slope in the Department of Chocó (Fig. 7). It is somewhat more likely that $P$. caucensis occurs sympatrically with $P$. bicornis, which is more widely distributed, though P. bicornis has not been recorded in Valle del Cauca to date (Luer 1999, Tropicos 2017).

There has recently increased interest in the orchid flora of the Department of Valle del Cauca, Colombia (Kolanowska 2014, Kolanowska et al. 2011, Kolanowska \& Szlachetcko 2014, ReinaRodríguez \& Tupac-Otero 2011, Rodríguez-Martínez et al. 2015). However, the region is undoubtedly understudied and deserves further attention in order to fully describe the orchid flora before climate change and deforestation cause even more habitat loss (ReinaRodríguez et al. 2016). The only known locality of the species described herein, $P$. caucensis, occurs in an unprotected area near Calima Lake where author Haelterman has observed other undescribed species of Pleurothallis in the nearby montane forest. A complete census of the orchid flora of this region could reveal multiple new species and further, provide support for forest protection in the future.

Relatively little is known about the pollination of species of Pleurothallis sensu Pridgeon et al. (2005), though most species are believed to be pollinated by
Diptera and a few by Coleoptera and Hymenoptera (Duque 1993, Calderón-Sáenz 2011, Duque-Buitrago et al. 2014). With regard to the role of labellar morphology in pollination in Pleurothallis sensu Pridgeon et al. (2005) even less is known (Dupree \& Wilson 2016, Wilson et al. 2016). Other genera in subtribe Pleurothallidinae have been studied in much greater depth, including Anathallis (CardosoGustavson 2014), Dracula (e.g. Policha et al. 2016), Lepanthes (Blanco \& Barboza 2005), Octomeria (Cardoso-Gustavson 2014), Restrepia (Millner \& Baldwin 2016), Specklinia (e.g. Karremans et al. 2015) and Stelis (Ignowski 2015, Ignowski et al. 2015). In some of these Pleurothallidinae a glenion is present on the hypochile of the lip which may act as a nectary-like tissue, producing a pollinator reward. In Pleurothallis the glenion is pronounced in subsections Macrophyllae-Fasciculatae (Wilson et al. 2016) and Acroniae (Wilson unpubl. data), but Luer (1999) stated that it is not usually developed in subsection Macrophyllae-Racemosae or Antenniferae.

Of the species studied here P. bicornis, P. caucensis, $P$. subreniformis and $P$. torrana all possess relatively simple lips. The flowers of $P$. caucensis appear to provide a liquid reward on the anterior margin of the central lobe of the labellum (Fig. 10), which is uppermost due to the apparently non-resupinate presentation of the flowers on the raceme (Fig. 1). While the glenion is not very distinct in P. caucensis, or the other species examined, at least compared to members of the MacrophyllaeFasciculatae (Wilson et al. 2016), there does appear to be secretion of a liquid from under the anther which forms a layer between the two calli on the anterior edge of the lip (Fig. 11). We hypothesize that a potential pollinator lands on the synsepal and is attracted to the liquid reward on the anterior edge of the labellum and then proceeds toward the anther in response to the liquid reward accumulating between the calli on the lip. Most likely this model based on P. caucensis also applies to other members of the Macrophyllae-Racemosae with a simple lip, such as the P. bicornis, P. subreniformis and P. torrana studied here.

Conclusions. Considered together, Pleurothallis subsections Macrophyllae-Racemosae and Antenniferae comprise the second most species-rich group in the genus after subsection Macrophyllae- 
Fasciculatae. Due to the difficulty in identification of members of this group, likely the species count is underestimated. Further, recent access to previously inaccessible areas of Colombia and northwestern Ecuador will likely reveal multiple new species. Pleurothallis caucensis described here is the first of a series of new species in the Macrophyllae-Racemosael Antenniferae group. In addition to taxonomic studies, in situ research into the pollination ecology of the group would be highly desirable.
ACKNOWLEDGEMENTS. The authors are grateful to Colorado College for research funding awarded to Wilson and Dupree, for greenhouse space and for herbarium access; to Dr. Ron Hathaway for assistance with SEM; to Ecuagenera for access to their plant collections and to members of the Portilla family for their warm hospitality; to Orquídeas del Valle for access to their plant collection and to Andrea Niessen for assistance; to Lynn O'Shaughnessy for creation and maintenance of the Pleurothallid Alliance website on which the species was first noticed; to Adam Karremans and Diego Bogarín for instruction in preparation of LCDPs; and to the Editors and the anonymous reviewers for suggestions on the manuscript.

\section{LITERATURE CITED}

Blanco, M. A. \& Barboza, G. (2005). Pseudocopulatory pollination in Lepanthes (Orchidaceae: Pleurothallidinae) by fungus gnats. Annals of Botany, 95, 763-772. Doi: http://dx.doi.org/10.1093/aob/ mci090

Calderón-Sáenz, E. (2011). Pleurothallis colossus: Pollination by Anthomyiid flies at El Refugio nature reservation. Orchids, 80(12), 740-743.

Cardoso-Gustavson, P. (2014). Desenvolvimento floral em espécies de Pleurothallidinae (Orchidaceae) com ênfase nas estruturas secretoras. (Ph.D. Thesis) Instituto de Botânica da Secretaria do Meio Ambiente, São Paulo, Brazil.

Dodson, C. H. (2003). Native Ecuadorian orchids, volume 4: Oncidium to Restrepiopsis. Sarasota, FL, U.S.A.: Dodson Trust.

Dodson, C. H. \& Dodson, P. M. (1980). Orchids of Ecuador, Series 1, Fascicles 1-4, Icones Plantarum Tropicarum. Sarasota, FL, U.S.A.: Marie Selby Botanical Gardens.

Dodson, C. H. \& Dodson, P. M. (1982). Orchids of Ecuador, Series 1, Fascicles 5, Icones Plantarum Tropicarum. Sarasota, FL, U.S.A.: Marie Selby Botanical Gardens.

Dupree, K. \& Wilson, M. (2016). Floral micromorphology and evolution of pollination by sexual deceit in Pleurothallis R.Br. (Orchidaceae; Pleurothallidinae) subgenera Ancipitia and Scopula. Abstract, Botany 2016, Botanical Society of America Annual Meeting.

Duque H., Ó. (1993). Polinización en Pleurothallis. Orquideología, 19(1), 55-69.

Duque, H., Ó. (2008). Orchidaceae Stelis Swartz compendium. Medellín, Colombia: Editorial Universidad de Antioquia.

Duque-Buitrago, C. A., Alzate-Quintero, N. F. \& Tupac Otero, J. (2014). Nocturnal pollination by fungus gnats of the Colombian endemic species, Pleurothallis marthae (Orchidaceae: Pleurothallidinae). Lankesteriana, 13(3), 407-417.

Escobar, R. (1994). Native Colombian orchids, volume 3,
Maxillaria-Ponthieva. Medellín, Colombia: Compañia Litográfica Nacional S.A.

Escobar, R. (2006). Native Colombian orchids, volumen 6, supplement: Leucochyle-Zootrophion. Medellín, Colombia: Compañia Litográfica Nacional S.A.

Ignowski, H. (2015). Stelis Swartz (Orchidaceae) no estado do Paraná e estudos micro-morfológicos florais do gênero. Ph.D. Thesis, Universidade Federal do Paraná, Brazil.

Ignowski, H., Toscano de Brito, A. L. V., Bona, C. \& de Camargo Smidt, E. (2015). Nomenclatural notes on Stelis ciliaris (Pleurothallidinae, Orchidaceae). Phytotaxa, 218(1), 30-38. Doi: http://dx.doi. org/10.11646/phytotaxa.218.1.2

Karremans, A. P., Pupulin, F., Grimaldi, D., Beentjes, K. K., Butôt, R., Fazzi, G. E., Kaspers, K., Kruizinga, J., Roessingh, P., Smets, E. F. \& Gravendeel, B. (2015). Pollination of Specklinia by nectar-feeding Drosophila: the first reported case of a deceptive syndrome employing aggregation pheromones in Orchidaceae. Annals of Botany, 116(3), 437-455. Doi: http://dx.doi. org/10.1093/aob/mcv086

Kolanowska, M. (2014). The orchid flora of the Colombian Department of Valle del Cauca. Revista Mexicana de Biodiversidad, 85, 445-462. Doi: http://dx.doi. org/10.7550/rmb.32511

Kolanowska, M., Pérez-Escobar, O. A., Sánchez, E. P. \& Szlachetko, D. (2011). An illustrated field guide to the orchids of the Yotoco Forest Reserve (Colombia). Polonia: Fundacja Rozwoju Uniwersytetu Gdańskiego.

Kolanowska, M. \& Szlachetko, D. L. (2014). Orchids of the Department of Valle del Cauca. Volume 3 Epidendroideae (Epidendreae-Pleurothallidinae). Koenigstein, Germany: Koeltz Scientific Books.

Lindley, J. (1859). Folia Orchidacea: an enumeration of the known species of orchids. London: J. Matthew.

Luer, C.A. (1974). Icones Pleurothallidinarum: Pleurothallis of Ecuador (Orchidaceae). Selbyana,1(1), 56-100. 
Luer, C. A. (1975a). Icones Pleurothallidinarum (Orchidaceae): Pleurothallis of Ecuador II. Selbyana, 1(2), 172-195.

Luer, C. A. (1975b). Icones Pleurothallidinarum (Orchidaceae): Pleurothallis of Ecuador III. Selbyana, 1(3), 220-303.

Luer, C. A. (1976). Icones Pleurothallidinarum: Miscellaneous species of Pleurothallis. Selbyana, 3(1-2), 38-201.

Luer, C. A. (1977). Icones Pleurothallidinarum (Orchidaceae): Miscellaneous species in the Pleurothallidinae. Selbyana, 3(3-4), 203-407.

Luer, C. A. (1986). Icones Pleurothallidinarum III: Systematics of Pleurothallis. Monographs in Systematic Botany from the Missouri Botanical Garden, 20, 1-109.

Luer, C. A. (1988). A revision of some sections of subgenus Pleurothallis. Lindleyana, 3(3), 133-149.

Luer, C. A. (1999) Icones Pleurothallidinarum XVIII: Systematics of Pleurothallis subgen. Pleurothallis, sect. Pleurothallis, subsect. Antenniferae, subsect. Longiracemosae, subsect. Macrophyllae-Racemosae, subsect. Perplexae, subgen. Pseudostelis, subgen. Acuminatia. Monographs in Systematic Botany from the Missouri Botanical Garden, 76, 1-182.

Luer, C. A. (2005). Icones Pleurothallidinarum XXVII: Dryadella and Acronia section MacrophyllaeFasciculatae. Monographs in Systematic Botany from the Missouri Botanical Garden, 103, 1-311.

Luer, C. A. (2009). Miscellaneous new species in the Pleurothallidinae (Orchidaceae). Selbyana, 30(1), 1-71.

Luer, C. A. (2011). Miscellaneous new species in the Pleurothallidinae (Orchidaceae) excluding species from Brazil. Harvard Papers in Botany, 16(2), 311-360.

Luer, C. A. \& Thoerle, L. (2013). Miscellaneous new species in the Pleurothallidinae (Orchidaceae). Harvard Papers in Botany, 18(2), 173-196.

Millner, H. J. \& Baldwin, T. C. (2016). Floral micromorphology of the genus Restrepia (Orchidaceae) and the potential consequences for pollination. Flora, 225, 10-19. Doi: http://dx.doi.org/10.1016/j. flora.2016.09.007

Policha, T., Davis, A., Barnadas, M., Dentinger, B. T. M., Raguso, R. A. \& Roy, B. A. (2016). Disentangling visual and olfactory signals in mushroom-mimicking Dracula orchids using realistic three-dimensional printed flowers. New Phytologist, 210(3), 1058-1071. Doi: http://dx.doi.org/10.1111/nph.13855

Pridgeon, A. M., Cribb, P.J., Chase, M. W. \& Rasmussen, F. N. (2005). Genera Orchidacearum. Volume 4. Epidendroideae (Part one), (385-390). Oxford, U.K.: Oxford University Press.
Pridgeon, A. M., Solano, R. \& Chase, M. W. (2001). Phylogenetic relationships in Pleurothallidinae (Orchidaceae): Combined evidence from nuclear and plastid DNA sequences. American Journal of Botany, 88, 2286-2308.

Reina-Rodríguez, G. A., \& Tupac-Otero, J. (2011). Guía ilustrada de las orquídeas del Valle geográfico del río Cauca y Piedemonte andino bajo. Santiago de Cali: Sociedad Vallecaucana de Orquideología. Universidad Nacional de Colombia, Sede Palmira.

Reina-Rodríguez, G. A., Rubiano, J. E., Castro Llanos, F. A. \& Tupac Otero, J. (2016). Spatial distribution of dry forest orchids in the Cauca River Valley and Dagua Canyon: Towards a conservation strategy to climate change. Journal for Nature Conservation, 30, 32-43. Doi: http://dx.doi.org/10.1016/j.jnc.2016.01.004

Rodríguez-Martínez, L., Rincón-Useche, C. \& Karremans, A. P. (2015). A new Pleurothallis from Colombia, with a note on Ancipitia and Colombiana (Orchidaceae: Pleurothallidinae). Systematic Botany, 40(1): 75-78. Doi: http://dx.doi.org/10.1600/036364415X686350

Tropicos (2017). Missouri Botanical Garden, Missouri, USA. Available from http://www.tropicos.org/Home. aspx (Accessed: June 10, 2017).

Wilson, M., Baquero, L., Dupree, K., Jiménez, M. M., LeBlanc, C. M., Merino, G., Portilla, J., Salas Guerrero, M., Tobar Suárez, F. \& Werner, J. D. (2016). Three new species of Pleurothallis (Pleurothallidinae; Orchidaceae) in subsection Macrophyllae-Fasciculatae from northern South America. Lankesteriana, 16(3), 349-366. Doi: http://dx.doi.org/10.15517/lank. v16i3.27314

Wilson, M., Belle, C., Dang, A., Hannan, P., Kenyon, C., Low, H., Stayton, T. \& Woolley, M. A. (2011). A phylogenetic analysis of the genus Pleurothallis, with emphasis on Pleurothallis subsection MacrophyllaeFasciculatae, using nuclear ITS and chloroplast DNA sequencing. Lankesteriana, 11(3), 369. Doi: http:// dx.doi.org/10.15517/lank.v11i3.18304

Wilson, M., Belle, C., Dang, A., Hannan, P., Kellogg, L., Kenyon, C., Low, H., Mochizuki, A., Nguyen, A., Sheade, N., Shan, L., Shum, A., Stayton, T., Volz, C., Vosburgh, B., Wellman, H. \& Woolley, M. A. (2013). Preliminary phylogenetic analysis of Pleurothallis sensu lato based upon nuclear and plastid sequences. Lankesteriana, 13(1-2), 139. Doi: http://dx.doi. org/10.15517/lank.v0i0.11568 
LANKESTERIANA

LANKESTERIANA 17(2). 2017. (C) Universidad de Costa Rica, 2017. 